Open Access

\title{
Erratum to: Europe and North East Asia, a complementary couple?
}

György Széll

Correspondence: gszell@uos.de University of Osnabrueck, School of Cultural \& Social Sciences, D-49069

Osnabrueck, Germany

\section{Erratum}

After publication of the original article (Széll Europe and North East Asia, a complementary couple?, 2016), it was discovered that a technical error had occurred in our system and the article was published with a duplicate citation, 1:1. The correct citation for the article (Széll Europe and North East Asia, a complementary couple?, 2016), should be 1:7. This has been updated in the original article (Széll Europe and North East Asia, a complementary couple?, 2016).

Received: 14 September 2016 Accepted: 14 September 2016

Published online: 03 October 2016

\section{Reference}

1. György, Széll. 2016. Europe and North East Asia, a complementary couple? Asian Journal of German and European Studies 1: 7. doi:10.1186/s40856-016-0008-8. 